\title{
Validity and reliability of Turkish version of the Brief Pain Inventory-Short Form for patients with chronic nonmalignant pain
}

\author{
Kronik nonmaling ağrısı olan hastalarda Brief Ağrı Envanteri Kısa Formu'nun \\ Türkçe formunun geçerliği ve güvenirliği
}

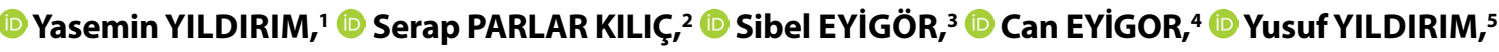

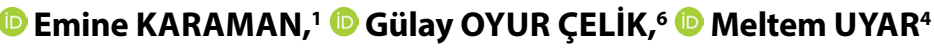

\begin{abstract}
Summary
Objectives: The aim of this study was to evaluate the validity and reliability of the Turkish version of the Brief Pain InventoryShort Form for patients with chronic nonmalignant pain.

Methods: An analytical design was used. A total of 192 patients were included in the study. A demographic questionnaire and the Brief Pain Inventory-Short Form were used to collect data. Content validity was assessed by experts and construct validity was tested using exploratory factor analysis. Reliability analyses estimated the internal consistency and test-retest reliability. Cronbach's alpha and the item-total correlations were calculated for the subscales to examine internal consistency.

Results: Exploratory factor analysis yielded 2 factors: pain severity and pain interference, which accounted for $68.81 \%$ of the total variance. The coefficient alpha of both subscales demonstrated good internal consistency. The item-total correlations of the scale ranged between 0.56 and 0.87 . The test-retest reliability was $r=0.774$ for pain severity and $r=0.808$ for pain interference $(p=0.001)$.

Conclusion: The Turkish version of the Brief Pain Inventory-Short Form is a valid and reliable instrument to assess chronic nonmalignant pain.
\end{abstract}

Keywords: Brief pain inventory short form; chronic nonmalignant pain; pain assessment; validity; reliability.

\section{Özet}

Amaç: Bu çalışmanın amacı, kronik nonmaling ağrısı olan hastalarda Brief Ağrı Envanteri Kısa Formu'nun Türkçe versiyonunun geçerliğini ve güvenirliğini değerlendirmektir.

Gereç ve Yöntem: Analitik çalışma deseni kullanıldı. Çalışmaya 192 hasta dahil edildi. Veri toplamada sosyodemografik soru formu ve Brief Ağrı Envanteri Kısa Formu kullanıldı. Envanterin geçerliğini değerlendirmek için içerik ve yapı geçerliği kullanılmıştır. ıçerik geçerliği uzman görüşü ile değerlendirildi. Yapı geçerliği için açımlayıcı faktör analizi kullanılmıştır. Güvenirlik analizi için iç tutarlıık ve test tekrar test güvenirlik analizleri yapılmıştır. İç tutarlılık için alt boyutların Cronbach alfa ve maddetoplam korelasyonları hesaplandı.

Bulgular: Açımlayıcı faktör analizi 2 faktör göstermiştir, ağrı şiddeti ve ağrı girişimi. İki faktör toplam varyansin \%68.81'ini açıklamıştır. Her iki alt boyutun alfa katsaysı iyi iç tutarlılık göstermiştir. Ölçeğin madde toplam korelasyonları 0.56 ile 0.87 arasındadır. Test-retest güvenirliği ağrı şiddeti için $r=0.774$ ve ağrı girişimi için $r=0.808^{\prime}$ dir $(p=0.001)$.

Sonuç: Brief Ağrı Envanteri Kısa Formu'nun Türkçe versiyonu, kronik nonmaling ağrıyı değerlendirmek için güvenilir ve geçerli bir araçtır.

Anahtar sözcükler: Brief ağrı envanteri kısa formu; nonmaling ağrı; ağrı değerlendirmesi; geçerlik; güvenirlik.

\footnotetext{
'Department of Internal Medicine Nursing, Ege University Faculty of Nursing, İzmir, Turkey

${ }^{4}$ Department of Anestesiology, Pain Clinic, Ege University Faculty of Medicine, İzmir, Turkey

${ }^{5}$ Department of Gynecological Oncology, İzmir, Turkey

Correspondence: Dr. Yasemin Yıldırım. Ege Üniversitesi Hemşireşik Fakültesi, Bornova 35100, İzmir, Turkey.

Phone: +90 - 232 - 3115538 e-mail: yasemin.kyildirim@ege.edu.tr

(c) 2019 Turkish Society of Algology

${ }^{2}$ Department of Internal Medicine Nursing, İnönü University Faculty of Health Sciences, Malatya, Turkey

${ }^{3}$ Department of Physical Therapy and Rehabilitation, Ege University Faculty of Medicine, İzmir, Turkey

${ }^{6}$ Department of Surgical Nursing, Izmir Katip Çelebi University Faculty of Health Sciences, İzmir, Turkey

Submitted (Başvuru tarihi) 24.02.2018 Accepted after revision (Düzeltme sonrası kabul tarihi) 18.04.2019 Available online date (Online yayımlanma tarihi) 13.06.2019 


\section{Introduction}

Chronic pain and its treatment are an important economic burden on healthcare systems. All over the world, it is the most common symptom that requires professional support. ${ }^{[1]}$ Affecting millions of people every year, chronic pain has a negative effect on the quality of life and causes physical, functional, and psychological problems. ${ }^{[2,3]}$ Patient assessment is the most important step in the management of chronic pain, which has both material and spiritual importance. ${ }^{[4]}$ Pain assessment is a major step in the diagnosis and treatment of the patients suffering from pain. ${ }^{[5]}$

Not only the severity of the pain, but also its duration, localisation, somatosensorial characteristics, and accompanying emotional symptoms should be taken into consideration. Nevertheless, pain control may be a problematic process due to the inadequacy of objective evaluation methods. ${ }^{[6,7]}$ Reliable and valid instruments can provide guidance for healthcare professionals in clinical practice in terms of pain assessment. The Brief Pain Inventory (BPI) was developed in 1994 by Cleeland and Ryan for two reasons; the subjective severity of pain and the interference caused by pain. The BPI is a valid, reliable, and commonly used scale which evaluates the localisation and severity of pain during the past 24 hours as well as its effect on activity in individuals with pain. ${ }^{[8]}$

It is a quick and useful scale with validity and reliability performed in different populations and different languages..$^{[9-16]}$ Although the BPI has been primarily used to assess cancer-related pain, it is validated for non-malignant pain, as well. ${ }^{[16,17]}$ Since chronic pain affects functional activity and psychology, these aspects of pain should also be assessed with regard to multidisciplinary treatment. The BPI allows to assess these aspects, as well. The BPI is comprised of two parts. The first part includes eight items which question pain location, pain severity, analgesic use, and pain relief. The second part evaluates the effect of pain on daily life activities. ${ }^{[8,18]}$ In Turkey, there have been no multi-dimensional scales except for the McGill Pain Questionnaire used to assess all aspects of pain. Although the BPI has been validated in several languages and tested in surgical patients in Turkey, a validated Turkish version of the inventory for patients with chronic nonmalignant pain has not been available until now. For this reason, the purpose of this study is to determine validity and reliability of the BPI-SF in patients with chronic nonmalignant pain, and to provide with a multi-dimensional scale to be used in chronic pain assessment in Turkey.

\section{Material and Method}

\section{Study Design}

This was a descriptive and psychometric study.

\section{Participant and Data Collection}

This study was conducted on both inpatients and outpatients in the clinic of physical therapy and rehabilitation, rheumatology, and algology at two university hospitals in Izmir and Gaziantep, Turkey. Inclusion criteria of patients were as follows; 1 ) being diagnosed with chronic pain by a specialist, 2) having a pain duration of at least three months, 3 ) being over the age of 18,4) being able to communicate verbally, and 5) giving informed consent. Patients who had a history of previous surgery in the last two weeks were excluded from the study due to the different nature of nonmalignant pain and surgical pain. Also, patients who were newly diagnosed with cancer were not included in the study. The sample group of the study consisted of 192 patients. The number of items in the BPI-SF $(n=9)$ was taken into consideration in determining the appropriate sample size for the study. At least 3 or more patients are recommended for each scale item in the scale study. ${ }^{[19]}$ The number of patients included in this study was twenty times of the number of BPI-SF items. In the study of the test-retest reliability of the scale, 30 patients were administered the same scale again after two weeks.

\section{Data Collection}

The pilot study was conducted among 10 patients with chronic pain in order to assess the comprehensibility and ease of use for the Turkish Brief Pain Inventory (BPI-SF-Tr). For application to larger study populations, the final version of the scale was formed. Patients who participated in the pilot study were not included in this study. All study data were collected by using face-to-face interview methods. The questions were read to the participants and then their answers were marked on the questionnaires.

Translation procedure for the Brief Pain Inventory 
(SF): Language validity of the scale was performed in the first step of the study. The original form of the BPI-SF was translated from English to Turkish by the research team (three nursing lecturers and four doctor lecturers) and also two native Turkish speakers who spoke English fluently (one was a nursing lecturer and the other one was an English lecturer who is also native English speaker). Then, two bilingual translators translated the Turkish items back into English. None of experts had seen the original English text of the scale. ${ }^{[1]}$ After we compared with the back-translated version and the original version, we found them to be nearly the same. No changes were made in them. Finally, the Turkish version of the BPISF was produced for final use upon consensus of the translation committee.

Validity of the Brief Pain Inventory (SF): Content validity and construct validity were performed to assess the validity of the BPI-SF. Content validity is conducted according to expert opinion and is related to whether questions on the assessment tool are in accordance with the measurement objective and represent the area intended to be measured or not. Content validity of the BPI-SF-Tr was assessed by four experts. These professionals comprised of two algologists and two algology nurses. These experts were asked to evaluate the each item of the BPI-SF over a $100 \%$ agreement level. ${ }^{[20]}$ And then, its final form was composed. Construct validity of the BPI-SF$\mathrm{Tr}$ was tested using exploratory factor analysis.

Firstly, permission for use of the BPI-SF was obtained from the author who developed the tool. Institutional approval was received from the Ethics Committee of Faculty of Nursing. Furthermore, written consent from the institutions and informed consent from each participant were taken.

Measures: Two instruments were used to collecting the data of the study. The demographic questionnaire was developed upon a literature review. The questionnaire included socio-demographic characteristics (gender, age, marital status, educational status, social security, employment, and economic condition) and medical characteristics (diagnosis of the disease, duration of disease, treatment, duration of pain, and intensity of the pain) of the patients. The BPI-SF is a patient-rated and easy-to-understand in- strument. Developed by Cleeland and Ryan (1994), the inventory allows patients to rate the severity of their pain and the degree to which their pain interferes with common dimensions of feeling and function. The BPI-SF measures their current, worst, least, and average pain during the past 24 hours. These four items are assessed by using a numeric scale, with $0=$ no pain and $10=$ pain as bad as you can imagine. The other seven items evaluates how much pain interfered with various daily activities, including general activity, walking, work, mood, enjoyment of life, relations with others, and sleep. Again, a 0 to 10 scale, with $0=$ no interference and $10=$ interferes completely, is used. ${ }^{[8,21]}$ The BPI-SF also retains the body diagram from the initial questionnaire and questions about effectiveness of pain treatment. ${ }^{[21]}$ The Cronbach's alpha reliability of the original version of the BPI ranges from 0.77 to $0.91 .^{[8]}$

\section{Statistical Analysis}

The Statistical Package for The Social Sciences 13.0 for Windows was used to conduct statistical analysis. $P$ values of less than 0.05 were accepted as statistically significant. Firstly, descriptive statistics were performed to assess characteristics of participants. Also, means and standard deviations were calculated for each item of the subscales. Secondly, reliability and validity analysis of the BPI-SF-Tr was carried out. Content validity and construct validity were calculated for assessing the validity of the BPI-SF-Tr. In order to examine construct validity, exploratory factor analysis was used. Principal component analysis for extraction method and varimax with Kaiser Normalization for rotation method were assessed. Cronbach's alpha coefficient and item total correlation were calculated to establish internal consistency reliability of the subscales. ${ }^{[20,22]}$ For the purpose of assessing the test-retest reliability for the scale, the Pearson correlation coefficient was performed.

\section{Results}

A total of seven patients were excluded from the sample group due to their refusal to participate in the study. Finally, 192 patients were included in this study. Table 1 illustrates socio-demographic and medical characteristics of the patients. As shown in Table, $64.6 \%$ were female, $78.6 \%$ were married, and $45.9 \%$ were primary school graduates. The mean age was $49.35 \pm 15.49$ (range 17 to 84 ) years. 
Table 1. Characteristics of the sample

\begin{tabular}{|c|c|c|}
\hline & Frequency & Percentage \\
\hline \multicolumn{3}{|l|}{ Gender } \\
\hline Female & 124 & 64.6 \\
\hline Male & 68 & 35.4 \\
\hline \multicolumn{3}{|l|}{ Marital status } \\
\hline Married & 151 & 78.6 \\
\hline Single & 41 & 21.4 \\
\hline \multicolumn{3}{|l|}{ Level of education } \\
\hline Literate & 24 & 12.5 \\
\hline $\begin{array}{l}\text { Primary school } \\
\text { (age } 7 \text { to } 12 \text { ) }\end{array}$ & 88 & 45.9 \\
\hline $\begin{array}{l}\text { Secondary school } \\
\text { (age } 13 \text { to } 17 \text { ) }\end{array}$ & 43 & 22.4 \\
\hline University & 37 & 19.3 \\
\hline \multicolumn{3}{|l|}{ Occupation } \\
\hline Employee & 58 & 30.2 \\
\hline Selfemployed & 11 & 5.7 \\
\hline Retired & 41 & 21.4 \\
\hline Housewife & 82 & 42.7 \\
\hline \multirow[t]{2}{*}{ Total } & 192 & 100.0 \\
\hline & Mean & SD \\
\hline Age (years) & 49.35 & 15.49 \\
\hline Duration of disease (years) & 4.34 & 4.74 \\
\hline Duration of pain (years) & 3.52 & 3.94 \\
\hline
\end{tabular}

SD: Standard deviation.

All patients had health insurance and $64.1 \%$ were not currently working (retired or a housewife). The mean time from the diagnosis was $4.34 \pm 4.74$ (range one to 25) years. The mean duration of pain was $3.52 \pm 3.94$ years.

\section{Descriptive results of the Turkish Brief Pain Inventory (SF)}

Table 2 illustrates descriptive statistics for each item of the subscales. The mean worst pain score was $6.99 \pm 2.11$ and the mean least pain was 3.22 \pm 2.17 . Patients reported that the highest score was obtained in pain's interference with general activity, which was followed by normal work, mood, enjoyment of life, sleep, walking ability, and relationship with other.

\section{Validity of the Turkish Brief Pain Inventory (SF)}

The Kaiser-Meyer-Olkin (KMO) measure of sampling adequacy value was 0.88 with a statistically signifi-
Table 2. Descriptive results of the BPI-Tr

\begin{tabular}{lll}
\hline BPI item & Mean & SD \\
\hline Pain Severity (0-10) & & \\
$\quad$ Pain worst & 6.99 & 2.11 \\
$\quad$ Pain least & 3.23 & 2.18 \\
$\quad$ Pain on average & 5.19 & 1.95 \\
$\quad$ Pain now & 5.11 & 2.52 \\
Pain interference (0-10) & & \\
$\quad$ General activity & 6.02 & 2.42 \\
$\quad$ Mood & 5.29 & 2.81 \\
$\quad$ Walking ability & 4.54 & 3.05 \\
$\quad$ Normal work & 5.98 & 2.54 \\
Relationships with others & 3.84 & 2.92 \\
$\quad$ Sleep & 4.81 & 3.11 \\
$\quad$ Enjoyment of life & 5.19 & 3.09 \\
\hline
\end{tabular}

BPI: Brief Pain Inventory; SD: Standard deviation.

Table 3. The 2 factors and factor loadings of the BPI-Tr items

\begin{tabular}{lcc}
\hline BPI item & $\begin{array}{c}\text { Factor I } \\
\text { (PI) }\end{array}$ & $\begin{array}{c}\text { Factor II } \\
\text { (PS) }\end{array}$ \\
\hline Pain severity & & \\
Pain worst & 0.53 & $\mathbf{0 . 6 5}$ \\
Pain least & 0.08 & $\mathbf{0 . 9 3}$ \\
Pain on average & 0.34 & $\mathbf{0 . 8 6}$ \\
Pain now & 0.22 & $\mathbf{0 . 8 4}$ \\
Pain interference & & \\
General activity & $\mathbf{0 . 6 3}$ & 0.57 \\
Mood & $\mathbf{0 . 8 1}$ & 0.20 \\
Walking ability & $\mathbf{0 . 7 1}$ & 0.10 \\
Normal work & $\mathbf{0 . 6 6}$ & 0.42 \\
Relationships with others & $\mathbf{0 . 7 9}$ & 0.18 \\
Sleep & $\mathbf{0 . 6 0}$ & 0.36 \\
Enjoyment of life & $\mathbf{0 . 8 2}$ & 0.23 \\
\hline
\end{tabular}

BPI: Brief Pain Inventory; SD: Standard deviation; PI: Pain interference; PS: Pain severity. The bold figures represent factor 1 and factor 2 .

cant Barlett sphericity (BS) ( $p=0.001)$. After exploratory factor analysis; it was loaded on two factors as pain intensity and pain interference in this study by using principal component extraction method with varimax rotation. Table 3 illustrates the two factors and factor loadings of the BPI items. The first factor consisted of all seven interference items and accounted for $55.5 \%$ of the variance. The second factor consisted of the four pain intensity scales and 
Table 4. Item analysis andinternal consistency of the BPI-Tr

\begin{tabular}{llll}
\hline BPI item & Item-total correlation & If Item deleted alpha & Cronbach alpha \\
\hline Pain severity (0-10) & & 0.89 & 0.89 \\
Pain worst & 0.70 & 0.86 & 0.83 \\
Pain least & 0.79 & 0.88 & \\
Pain on average & 0.87 & 0.87 & 0.89 \\
Pain now & 0.75 & 0.86 \\
Pain interference (0-10) & & 0.89 \\
General activity & 0.72 & 0.87 \\
Mood & 0.73 & 0.87 \\
Walking ability & 0.56 & 0.88 \\
Normal work & 0.71 & 0.86 \\
Relationships with others & 0.70 & \\
Sleep & 0.60 & 0.77 & 0.91 \\
Enjoyment of life & & \\
Total BPI-Tr & &
\end{tabular}

BPI: Brief Pain Inventory.

accounted for another $13.3 \%$ of the variance. Both factors accounted for $68.8 \%$ of the total variance. Factor loads of these two factors ranged from 0.60 to 0.93 . The eigenvalues of the two factors were 6.10 and 1.46 .

\section{Reliability of the Turkish Brief Pain Inventory (SF)} Internal consistency and test- retest reliability were performed in order to assess the reliability of the BPI. For the internal consistency, Cronbach's alphas and the item-total correlations were calculated for the pain interference and pain severity scales. The alpha coefficient was 0.89 for the pain severity scale, and 0.89 for the pain interferences scale. The total Cronbach's alpha coefficient was high as 0.91 for all items (BPI-SF-Tr) of the scale. All alpha values indicated good internal consistency. ${ }^{[23-25]}$ The item-total correlations of the scale ranged between 0.56 and 0.87 (Table 4). The item-total correlations for all items of the scale were adequate criteria. ${ }^{[20,26]}$ Table 4 illustrates the alpha values when items are deleted.

The test-retest reliability measurement was performed to assess the stability of the BPI-SF-Tr over time. After patients completed the BPI-SF-Tr, 30 patients were administered the same scale again two weeks later. Pearson correlations for test-retest reliability were $r=0.77, p=0.001$ for the pain severity, and $r=0.81, p=0.001$ for the pain interference.

\section{Discussion}

The this study has revealed that the BPI-SF-Tr is a valid and reliable instrument to assess pain severity and interference in patients with chronic nonmalignant pain. Validity refers whether an assessment instrument accurately measures what is supposed to measure or not. When an instrument is valid, it truly reflects the concept it is supposed to measure. ${ }^{[20]}$ Three types of validity are content validity, criterion-related validity, and construct validity. ${ }^{[24]}$ The content validity and construct validity were performed for validity of this study. Construct validity was confirmed by using the factor analysis. The KMO and BS are used to assess the adequacy for factor analysis of data. For factorability, KMO should be greater than $0.4{ }^{[27]} \mathrm{KMO}$ and $B S$ values obtained in this study showed that the sample size and correlation matrix of the scale items were suitable for factor analyses. ${ }^{[22,27]}$ After factor analysis, a total of 11 items were loaded on two factors as pain severity and pain interference. This result is consistent with numerous other factor analysis results in many different countries. ${ }^{[8-12,14,15]}$ Only two studies reported three factors: pain severity, pain activity, and mood interference. ${ }^{[13,28]}$

Reliability is consistency among independent measurements of the same variable. ${ }^{[24,28]}$ The reliability of an assessment tool refers to the tool producing consistent, adequate, homogeneous, repeatable results. 
Table 5. Reliability coefficient of the pain severity and pain interference bubscales of the various versions of the BPI

\begin{tabular}{lcc}
\hline Country & $\begin{array}{c}\text { PS } \\
\mathbf{a}\end{array}$ & $\begin{array}{c}\text { PI } \\
\mathbf{a}\end{array}$ \\
\hline Brazil & 0.91 & 0.87 \\
China & 0.86 & 0.91 \\
France & 0.86 & 0.90 \\
Germany & 0.88 & 0.92 \\
Greece & 0.89 & 0.85 \\
Italy & 0.78 & 0.78 \\
Japan & 0.81 & 0.81 \\
Lebanon & 0.82 & 0.92 \\
North India & 0.89 & 0.91 \\
Norway & 0.87 & 0.92 \\
Russia & 0.93 & 0.95 \\
Taiwan & 0.81 & 0.89 \\
Turkey & $\mathbf{0 . 8 9}$ & $\mathbf{0 . 8 9}$ \\
\hline
\end{tabular}

BPI: Brief Pain Inventory; PI: Pain interference; PS: Pain severity. Bolded numbers are results of the present study in Turkey.

${ }^{[29]}$ The reliability of an assessment instrument is the extent to which it yields consistent, reproducible estimates of what is assumed to be an underlying true score. ${ }^{[30]}$ There is an inverse relationship between reliability and random error. Despite its necessity, reliability alone is not sufficient for validity. ${ }^{[24,28]}$ In order to assess the reliability of the BPI, internal consistency and test-retest reliability were performed.

Internal consistency is usually measured with Cronbach's alpha. Cronbach's alpha reliability coefficient is the indicator of the homogeneity of the items included in the scale. ${ }^{[23,24]}$ Internal consistency ranges between 0 and one ${ }^{[23,25,28]}$ and literature suggests that a reliability of 0.70 is considered as acceptable. [33-36] An alpha within the range of 0.80 and 0.90 was accepted as good internal consistency. ${ }^{[23-25]}$ In this study, both coefficient alphas of the subscales and the total scale were above 0.80 . The Cronbach's alpha coefficient values indicated that items correlated with each other and the BPI-SF-Tr were reliable. ${ }^{[23]}$ When Cronbach's alpha coefficient values obtained in this study were compared to other BPI validation studies, it was found in some cases higher than those reported in other studies (Table 5) ${ }^{[9,10]}$ The acceptable item-total correlation for each item should be 0.30 and items with a correlation coefficient lower than 0.30 generally are recommended to be omitted from the scale. ${ }^{[20,26]}$ Because the item total correlations for each item were above 0.30 , any item from these two subscales was not eliminated. ${ }^{[28]}$

Test-retest reliability measures the stability over time. For test-retest analyses, the group should consist of at least 30 people, and the duration between two tests should be short enough to remember the answers given in the first application, and long enough to allow a considerable change in responders in terms of the features measured by the scale. ${ }^{[28]} \mathrm{A}$ typical interval is several weeks. ${ }^{[24]}$ The results of test-retest study showed an acceptable correlation coefficient for the BPI-SF-Tr.

\section{Conclusion}

The study confirmed that the BPI-SF in patients with chronic nonmalignant pain was determined to be a valid and reliable instrument for Turkish populations. It can be used as a tool for comprehensive pain assessment in patients suffering from chronic nonmalignant pain. It is recommended that this scale should be further evaluated both in different regions of Turkey with larger samples and in diverse populations.

\section{Acknowledgements: The authors thank all patients who participated in the study.}

Conflict-of-interest issues regarding the authorship or article: None declared.

Peer-rewiew: Externally peer-reviewed.

\section{References}

1. Davis DB. Caring for people in pain. Florence, KY: Routledge; 2000. p. 159-78.

2. Elliott TE, Renier CM, Palcher JA. Chronic pain, depression, and quality of life: correlations and predictive value of the SF-36. Pain Med 2003;4:331-9. [CrossRef]

3. Lapane KL, Quilliam BJ, Benson C, Chow W, Kim MS. Impact of Noncancer Pain on Health-Related Quality of Life. Pain Pract 2015;15(4):333-42. [CrossRef]

4. Polomano RC, Dunwoody CJ, Krenzischek DA, Rathmell JP. Perspective on pain management in the 21 st century. J Perianesth Nurs 2008;23(1 Suppl):4-14. [CrossRef]

5. Comley AL, De Meyer E. Assessing patient satisfaction with pain management through a continuous quality improvement effort. J Pain Symptom Manage 2001;21(1):27-40.

6. McCaffery M, Ferrell BR, Pasero C. Nurses' personal opinions about patients' pain and their effect on recorded assessments and titration of opioid doses. Pain Manag Nurs 2000;1(3):79-87. [CrossRef] 
7. Gordon DB, Pellino TA, Miaskowski C, Mc Neill JA, Paice JA, Laferriere $D$, et al. A 10-year review of quality improvement monitoring in pain management: Recommendations for standardized outcome measures. Pain Manag Nurs 2002;3:116-30. [CrossRef]

8. Cleeland CS, Ryan KM. Pain assessment: Global use of the Brief Pain Inventory. Ann Acad Med Singapore 1994;23(2):129-38.

9. Saxena A, Mendoza T, Cleeland CS. The Assessment of cancer pain in North India:The validation of the Hindi Brief Pain Inventory-BPI-H. J Pain Symptom Manage 1999;17:27-41.

10. Mystakidou K, Mendoza T, Tsilika E, Befon S, Parpa E, Bellos $G$, et al. Greek Brief Pain Inventory: Validation and utility in cancer pain. Oncology 2001;60(1):35-42. [CrossRef]

11. Yun YH, Mendoza TR, Heo DS, Yoo T, Heo BY, Park HA, et al. Development of a cancer pain assessment tool in Korea: a validation study of a Korean version of the brief pain inventory. Oncology 2004;66(6):439-44. [CrossRef]

12. Aisyaturridha A, Naing L, Nizar AJ. Validation of the Malay Brief Pain Inventory questionnaire to measure cancer pain. J Pain Symptom Manage 2006;31(1):13-21. [CrossRef]

13. Dicle A, Karayurt Ö, Dirimese E. Validation of the Turkish Version of the Brief Pain Inventory in surgery patients. Pain Manag Nurs 2009;10(2):107-13. [CrossRef]

14. Ferreira KA, Teixeira MJ, Mendonza TR, Cleeland CS. Validation of brief pain inventory to Brazilian patients with pain. Support Care Cancer 2011;19(4):505-11. [CrossRef]

15. Ballout S, Noureddine S, Huijer HA, Kanazi G. Psychometric evaluation of the Arabic Brief Pain Inventory in a sample of Lebanese cancer patients. J Pain Symptom Manage 2011;42(1):147-54. [CrossRef]

16. De Andres J, Cruces Prado LM, Canos Verdecho MA, Penide Villanueva L, Hoyos DVM, Herdman $M$, et al. Validation of the Short Form of the Brief Pain Inventory (BPI-SF) in Spanish Patients with Non-Cancer-Related Pain. Pain Pract 2015;15(7):643-53. [CrossRef]

17. Upadhyay C, Cameron K, Murphy L, Battistella M. Measuring pain in patients undergoing hemodialysis: a review of pain assessment tools. Clin Kidney J 2014;7(4):367-72.

18. Niklasson B, Georgsson Ohman S, Segerdahl M, Blanck A. Risk factors for persistent pain and its influence on maternal wellbeing after cesarean section. Acta Obstet Gynecol Scand 2015;94(6):622-8. [CrossRef]

19. Erdoğan S. Ölçümlerde Geçerlilik ve Güvenilirlik. Ankara, 2014;56-189.

20. Lobiondo-Wood G, Haber J. Reliability and validity. In: G. Lobiondo-Wood, Haber J, editors. Nursing research methods, critical appraisal, and utilization. 5th ed. St. Louis: Mosby; 2002. p. 311-46.

21. Cleeland CS. The Brief Pain Inventory User Guide 2009. Available at: https://www.mdanderson.org/documents/ Departments-and-Divisions/Symptom-Research/BPI_ UserGuide.pdf. Accessed December 13, 2011.

22. Akgül A. Tıbbi araştırmalarda istatistiksel analiz teknikleri SPSS uygulamaları. 3rd ed. Ankara: Emek Ofset; 2005. p. 440-6.

23. Tezbaşaran AA. Likert tipi ölçek geliştirme kılavuzu. Ankara:Türk Psikologlar Derneği; 1997.

24. Erefe I. Veri Toplama Araçlarının Niteliği. In: Erefe I, editor. Hemsirelikte Arastirma. Istanbul: Odak Ofset; 2002. p.16988.

25. George D, Mallery P. SPSS for windows step by step: A simple guide and reference. 11.0 update. 4th ed. Boston: Allyn \& Bacon; 2003.

26. Farketich S. Focus on psychometrics: aspects of item analysis. Res Nurs Health 1991;14(2):165-8. [CrossRef]

27. Büyüköztürk Ş. Sosyal Bilimler İçin Veri Analizi El Kitabı. Ankara: Pegem Akademi; 2009.

28. Karasar N. Bilimsel Arastırma Yontemi. 7th ed. Ankara: 3A Araştırma Eğitim Danışmanlık Ltd; 1995;147-53.

29. Çakmur H. Araştırmalarda Ölçme Güvenilirlik-Geçerlilik. TAF Preventive Medicine Bulletin 2012;11:339-44. [CrossRef]

30. American Thoracic Society, Quality of Life Resource. Available at: http://qol.thoracic.org/sections/measurementproperties/reliability.html. Accessed March 27, 2015. 